\title{
APPLICATION OF MONTMORILLONITE, ZEOLITE AND HYDROTALCITE NANOCOMPOSITE CLAYS-DRUG AS DRUG CARRIER OF SUSTAINED RELEASE TABLET DOSAGE FORM
}

\begin{abstract}
1. Faculty of Mathematic and Natural Science, Sebelas Maret University, Jl. Ir. Sutami 36A, Surakarta 57126

2.Faculty of Pharmacy, Setia Budi University, Jln. Let.Jen Sutoyo, Surakarta 57127
\end{abstract}

Submitted: $13-02-2014$

Revised: 04-04-2014

Accepted: 20-05-2014

*Corresponding author Ahmad Ainurofiq

Email :

rofiq_uns@yahoo.co.id

\author{
Ahmad Ainurofiq $^{1 *}$, Syaiful Choiri ${ }^{2}$
}

\begin{abstract}
Captopril is an angiotensin converting enzyme (ACE) inhibitor as antihypertensive treatment with half-life about $2 \mathrm{~h}$. Development of sustained-release dosage form can maintenance the drug concentration at therapeutic window in long period of time with constant release. Montmorillonite, zeolite and hydrotalcite nano-composites were used as drug carrier as sustained release dosage form. This study aimed to determine the drug release from nanocomposite of montmorillonite-drug, zeolitedrug and hydro-talcite-drug. Nanocomposite drug and carriers were made with the model drug was dispersed in carrier with matrix system. Matrices used montmorillonite, zeolite and hydrotalcite with concentrations of $20 \%, 30 \%$ and $40 \%$. Characterization of matrices were done by testing the physical properties of the granules and drug release. Dissolution test using apparatus II USP model with speed rotation of $50 \mathrm{rpm}$ of, $900 \mathrm{~mL}$ of $\mathrm{HCl} 0.1 \mathrm{~N}$ as medium. The results were compared statistically with one way ANOVA $95 \%$ of interval confidence. The results showed that the difference of matrices and concentrations gave the difference effect in flow time, compact-tibility, $D E_{360}$, initial burst release and maintenance release $(p<0.05)$. Nanocomposites between drug and nanoclays occurred after $60 \mathrm{~min}$ were shown with decreasing the drug release rate. Nanocomposite was formed with the drug molecules adsorb on nanoporous of carrier material. Increasing of clays concentration improved the fluidity and compactibility, reduced the drug release.
\end{abstract}

Key words: Nanocomposite, clays, drug release

\section{INTRODUCTION}

Captopril is a first active orally angiotensin converting enzyme inhibitor, the enzyme responsible to inhibits the formation of angiotensin II effectively for hypertensive treatment (Donald et al., 1982). Given orally, captopril is absorbed rapidly, has a bioavailability of $75 \%$. Peak concentration in plasma occur within an hour, and a half-life of about $2 \mathrm{~h}$. The oral dose of captopril ranges from 6.25 to $150 \mathrm{mg}$ twice or three times daily (Brunton et al., 2008). Strategy in development of sustained release dosage form to maintain drug at therapeutic levels in the long term. Captopril sustained release dosage form is considered to provide benefits by reducing the frequency of drug administration, improve the patient compliance. Therefore the effectiveness of treatment can be achieved and reduce the side effect (Collet and Moreton, 2002).

Montmorillonite, zeolite and hydrotalcite are one type of natural clays. Montmorillonite consist of large layer and insoluble cation are bound weakly to the space between the layer (Wijaya et al., 2004). Clays have three properties (swelling ability, cation/anion exchange and intercalation), with the abilities were developed as nano carriers of nanocomposite drug-clays for controlled release drug delivery (Hua et al., 2010; Zheng et al., 2007). Montmorillonite have average porous size (nanoporous) of about 15 $\AA(1.5 \mathrm{~nm})$ (Figure 1) which was called basal spacing (Ainurofiq et al., 2010). Nanocomposite drug-clays naturally occur drug to be loaded into the nanoporous as nanocomposite (Suresh et al., 2010). The natural montmorillonite and 


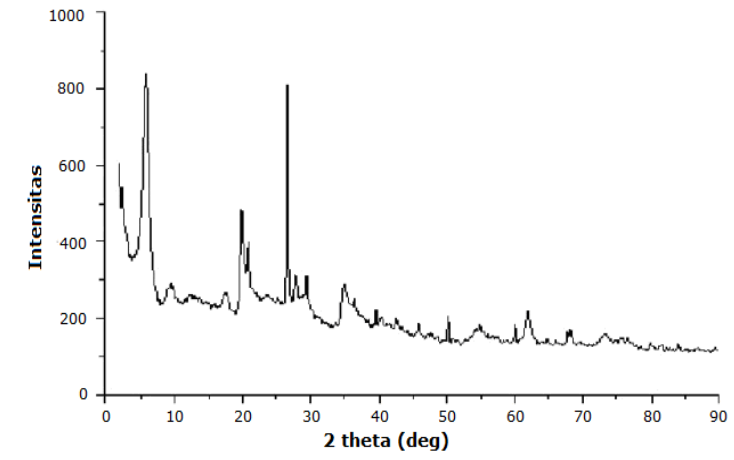

Figure 1. XRD pattern of natural montmorillonit with basal spacing $1.5 \mathrm{~nm}$

pillarization of montmorillonite with various molecular weight of chitosan (small, medium, and high) could release the drug slowly from dosage form using a poorly soluble drug (theophylline) (Ainurofiq et al., 2010).

Zeolite have cavity (porous) smaller than mesoporous material, and these characteristics can be used to achieve the more effective controlled release drug delivery. Pore size of nanoporous and mesoporous materials as the host determine the size of the drug molecules to be adsorbed into the pore. Adsorption and release of the molecules in the matrix is controlled by size selectivity. The pore size can provide better controlled drug release (Gonzales et al., 2013). The nanocomposite of drug-zeolite, the composite combined with biodegradable polymers (chitosan, gelatin, and alginate) and the drug loaded in the nanoporous of zeolite provided prolong drug release (Zhang et al., 2007).

Hydrotalcite (anionic clays) or layered double hydroxides are two dimensional material, these material is natural hydrotalcite with the brucite structure, where for each set of eight $\mathrm{Mg}^{2+}$ cation, two are substituted by $\mathrm{Al}^{3+}$. The positive charge in excess is balanced by carbonate anions hosted together with water molecules in the interlayer (Cavani et al., 1991). The intercalation of these anions clays, and their high affinity to carbonate ion to acid dissolution is able to the loaded drug in the interlayer. The composite between drug (ketoprofen, sodium diclofenac, and chloramphenicol succinate) and hydrotalcite, the drug release slowly up to $24 \mathrm{~h}$ (San Roman et al., 2013).
This study aimed to determine the drug release (kinetic models and characteristics) from nanocomposite of nanoclays (zeolite, hydrotalcite and montmorillonite) with dispersion in matrix system using captopril as water soluble drug from sustained release tablet dosage form.

\section{MATERIAL AND METHODS}

Captopril (Afine Chemicals, China), lactose (DFE Pharma, Germany), nature montmorillonite from Wonosegoro, Boyolali, Central Java, nature zeolite from Gunung Kidul, Yogyakarta, magnesium stearate (Bratachem, Indonesia), hydrotalcite (Sigma Aldrich, Singapore), hydrocloric acid p.a (Merck, Germany), $\mathrm{K}_{3}\left[\mathrm{Fe}(\mathrm{CN})_{6}\right]$ p.a (Merck, Germany), $\mathrm{FeCl}_{3}$ p.a (Merck, Germany), demineralized water.

\section{Purification of montmorillonite}

Montmorillonite had been purified from bentonite, coarse bentonite, were washed with demineralized water. The colloid phase was precipitated over night and dried in oven at temperature of $110^{\circ} \mathrm{C}$ and rewashed three times. Montmorillonite were sieved with 180 mesh sieve.

\section{Purification of zeolite}

Zeolite were washed with demineralized water, and the colloid phase were precipitated for one night. The sediment were then over rewashed three times The residue were dried in oven at temperature of $100^{\circ} \mathrm{C}$ for $6 \mathrm{~h}$ followed by refluxed with $500 \mathrm{~mL}$ of $\mathrm{HCl} 0.1 \mathrm{~N}$ and for $5 \mathrm{~h}$ at temperature $90^{\circ} \mathrm{C}$. The resulted material were washed with demineralized water until the neutral $\mathrm{pH}$. Zeolite, eventually it was washed with $500 \mathrm{~mL}$ of $\mathrm{NaOH} 0.75 \mathrm{~N}$ to build the ratio proportion of silica and aluminum followed by demineralized water until the neutral $\mathrm{pH}$. The precipitate were dried at $110^{\circ} \mathrm{C}$ for $6 \mathrm{~h}$. The dried zeolite were sieved with 180 mesh sieve.

\section{Preparation of captopril tablet}

Tablets were formulated according to Table I. Wet granulation method was employed for formulation. All of the component in formula except lubricant ( $1 \%$ magnesium stearate) were mixed in the mixer for $16 \mathrm{~min}$ $25 \mathrm{rpm}$ followed by addition of demineralized 
Table I. Composition formula of captopril tablet

\begin{tabular}{|c|c|c|c|c|c|c|}
\hline \multirow{2}{*}{ Formula } & \multicolumn{6}{|c|}{ Composition(mg) } \\
\hline & Captopril & Zeolit & Hydrotalcite & Montmorillonite & Lactose & Mg stearat \\
\hline F1 & 50 & - & - & - & 197.5 & 2.5 \\
\hline $\mathrm{F} 2$ & 50 & 50 & - & - & 147.5 & 2.5 \\
\hline F3 & 50 & 75 & - & - & 122.5 & 2.5 \\
\hline $\mathrm{F} 4$ & 50 & 100 & - & - & 97.5 & 2.5 \\
\hline F5 & 50 & - & 50 & - & 147.5 & 2.5 \\
\hline F6 & 50 & - & 75 & - & 122.5 & 2.5 \\
\hline F7 & 50 & - & 100 & - & 97.5 & 2.5 \\
\hline F8 & 50 & - & - & 50 & 147.5 & 2.5 \\
\hline F9 & 50 & - & - & 75 & 122.5 & 2.5 \\
\hline F10 & 50 & - & - & 100 & 97.5 & 2.5 \\
\hline
\end{tabular}

water to the blend until elastic mass of wet granules. Mass of wet granules were sieved with 16 mesh sieve. Wet granules were dried in oven at $40^{\circ} \mathrm{C}$ for $6 \mathrm{~h}$. The dried granules were mixed with magnesium stearate in mixer for $4 \mathrm{~min}$ $25 \mathrm{rpm}$. The granules were characterized by particle size distribution test with analytical sieving, moisture content, bulk density and tapped density. The mass of tablets were characterized by fluidity and compact-tibility test. The compactibility test was done with the deepness of upper punch of $5.3 \mathrm{~mm}$ and the lower punch of $8.15 \mathrm{~mm}$.

The tablet compression process, the weight of tablet was arranged at $250 \mathrm{mg}$ and the hardness was controlled at $10-12 \mathrm{~kg}$.

\section{Drug release}

Drug release was determined using dissolution tester type apparatus II (paddle method), where $900 \mathrm{~mL}$ of $\mathrm{HCl} 0.1 \mathrm{~N}$ was used as dissolution medium maintained at $37 \pm 0.05^{\circ} \mathrm{C}$ at $50 \mathrm{rpm}$ for $6 \mathrm{~h}$. Aliquots of $10 \mathrm{~mL}$ were withdraw at $15,30,45,60,90,120,180$, 240,300 , and $360 \mathrm{~min}$ with replacement of $10 \mathrm{~mL}$ of the fresh media. All the samples were analyzed directly at $202.4 \mathrm{~nm}\left(\lambda_{\max }\right.$ of captopril) using UV-Vis Hitachi U-2900 spectrophotometer.

\section{Drug release kinetics}

Drug release kinetics is assumed to reflect different release mechanism of controlled release matrix system. Therefore, six kinetic models were applied to analyze the drug release data to find the best fitting equation.
These models are zero-order release, first-order release, Hixcon-Crowell, Weibull, Higuchi release and Korsmeyer-Peppas. The release mechanism based on the exponential diffusion value $(n)$ of Korsmeyer Peppas equation. The best fitting equation based on coefficient of determination $\left(\mathrm{R}^{2}\right)$, AIC (Akaike's Information Criterion) and RMSE (root mean square eror).

\section{Analysis of result}

The results obtained were analyzed statistically, with normal distribution followed by one way ANOVA with $95 \%$ of confidence interval, if significant different followed by tLSD test. The drug releases were computed by free open source software, KinetDS ${ }^{\circledR}$ (Mendyk et al., 2012).

\section{RESULT AND DISCUSSION}

According on the results of physical properties tablet mass (Table II), granule using matrix montmorillonit showed the best physical properties tablet mass between zeolite and hydrotalcite, by fluidity and compactibility. Increasing matrix concentration enhanced the physical properties of captopril granules. Granules have good fluidity if flow time of $100 \mathrm{~g}$ of granules not more than $10 \mathrm{~s}$ and the angle of repose is less than $30^{\circ}$ (Fudholi, 1983). The fluidity was influenced by some factor such as moisture content, granules density, particle size distribution, porosity and cohesiveness interparticulate. The particle size distribution characteristic showed that fines (particle size less than $180 \mu \mathrm{m}$ ) in granules not should be more than $10 \%$. 
Table II. Physical properties of captopril tablets mass (mean \pm SD)

\begin{tabular}{cccccccc}
\hline Formula & $\begin{array}{c}\text { Bulk density Tapped density } \\
(\mathrm{g} / \mathrm{mL})\end{array}$ & $\begin{array}{c}\text { moisture } \\
(\mathrm{g} / \mathrm{mL})\end{array}$ & $\begin{array}{c}\text { flow time } \\
\text { content }(\%)\end{array}$ & $\begin{array}{c}\text { Compact- } \\
(\mathrm{sec})\end{array}$ & $\begin{array}{c}\text { angle of } \\
\text { tibility }(\mathrm{kg})\end{array}$ & $\begin{array}{c}\text { fines } \\
\text { repose }(\mathrm{o})\end{array}$ & $\begin{array}{c}\%) \\
(\%)\end{array}$ \\
\hline F1 & $0.629 \pm 0.01$ & $0.731 \pm 0.01$ & $0.50 \pm 0.00$ & $5.08 \pm 0.38$ & $1.28 \pm 0.16$ & $24.90 \pm 0.81$ & $3.08 \pm 0.29$ \\
F2 & $0.667 \pm 0.01$ & $0.709 \pm 0.02$ & $1.80 \pm 0.17$ & $6.26 \pm 0.11$ & $5.18 \pm 0.53$ & $24.00 \pm 1.24$ & $3.15 \pm 0.86$ \\
F3 & $0.658 \pm 0.01$ & $0.721 \pm 0.01$ & $2.30 \pm 0.00$ & $5.02 \pm 0.12$ & $6.08 \pm 0.46$ & $24.20 \pm 1.45$ & $4.60 \pm 0.82$ \\
F4 & $0.658 \pm 0.02$ & $0.727 \pm 0.01$ & $2.00 \pm 0.00$ & $4.16 \pm 0.09$ & $6.65 \pm 0.82$ & $25.40 \pm 0.89$ & $3.68 \pm 0.71$ \\
F5 & $0.538 \pm 0.00$ & $0.581 \pm 0.01$ & $1.20 \pm 0.17$ & $5.40 \pm 0.21$ & $3.94 \pm 0.45$ & $26.15 \pm 0.35$ & $2.89 \pm 0.23$ \\
F6 & $0.602 \pm 0.00$ & $0.694 \pm 0.00$ & $1.33 \pm 0.29$ & $4.57 \pm 0.07$ & $5.97 \pm 0.48$ & $24.88 \pm 0.28$ & $2.79 \pm 1.46$ \\
F7 & $0.704 \pm 0.00$ & $0.848 \pm 0.00$ & $2.00 \pm 0.50$ & $5.29 \pm 0.16$ & $6.70 \pm 0.68$ & $24.70 \pm 0.49$ & $6.45 \pm 1.82$ \\
F8 & $0.667 \pm 0.00$ & $0.767 \pm 0.01$ & $1.00 \pm 0.00$ & $5.07 \pm 0.22$ & $7.24 \pm 0.19$ & $24.43 \pm 1.52$ & $3.12 \pm 1.04$ \\
F9 & $0.816 \pm 0.00$ & $0.984 \pm 0.00$ & $1.00 \pm 0.00$ & $4.13 \pm 0.24$ & $10.31 \pm 0.74$ & $22.96 \pm 0.40$ & $0.33 \pm 0.06$ \\
F10 & $0.800 \pm 0.00$ & $0.948 \pm 0.04$ & $1.30 \pm 0.58$ & $3.65 \pm 0.13$ & $13.25 \pm 0.92$ & $20.86 \pm 0.59$ & $1.08 \pm 0.90$ \\
\hline
\end{tabular}

Tabel III. Physical properties of captopril tablet and the release rate (mean \pm SD)

\begin{tabular}{cccccc}
\hline Formula & $\begin{array}{c}\text { Hardness } \\
(\mathrm{kg})\end{array}$ & $\begin{array}{c}\text { Drug content } \\
(\%)\end{array}$ & $\begin{array}{c}\mathrm{DE}_{360} \\
(\%)\end{array}$ & $\begin{array}{c}\text { Initial burst release } \\
(\mathrm{mg} / \mathrm{min})\end{array}$ & $\begin{array}{c}\text { Maintenance } \\
\text { release }(\mathrm{mg} / \mathrm{min})\end{array}$ \\
\hline F1 & $4.52 \pm 0.28$ & $96.29 \pm 2.85$ & $90.64 \pm 3.42$ & $0.8802 \pm 0.0083$ & $0.0058 \pm 0.0019$ \\
F2 & $10.15 \pm 1.19$ & $99.19 \pm 1.07$ & $83.90 \pm 2.15$ & $0.6274 \pm 0.0270$ & $0.0319 \pm 0.0109$ \\
F3 & $10.21 \pm 0.23$ & $100.85 \pm 4.34$ & $74.15 \pm 1.61$ & $0.4486 \pm 0.0114$ & $0.0646 \pm 0.0052$ \\
F4 & $10.42 \pm 0.57$ & $97.99 \pm 3.96$ & $56.59 \pm 5.76$ & $0.3356 \pm 0.0414$ & $0.0552 \pm 0.0037$ \\
F5 & $11.46 \pm 0.78$ & $96.92 \pm 4.33$ & $81.22 \pm 2.26$ & $0.5928 \pm 0.0594$ & $0.0361 \pm 0.0058$ \\
F6 & $10.98 \pm 0.72$ & $96.29 \pm 4.23$ & $68.34 \pm 2.90$ & $0.4319 \pm 0.0253$ & $0.0598 \pm 0.0105$ \\
F7 & $10.44 \pm 0.98$ & $101.88 \pm 3.11$ & $69.62 \pm 3.82$ & $0.4049 \pm 0.0251$ & $0.0665 \pm 0.0063$ \\
F8 & $11.39 \pm 0.74$ & $99.43 \pm 0.86$ & $68.96 \pm 5.48$ & $0.5702 \pm 0.0564$ & $0.0296 \pm 0.0023$ \\
F9 & $11.32 \pm 0.78$ & $98.58 \pm 1.14$ & $65.62 \pm 3.04$ & $0.4352 \pm 0.0189$ & $0.0455 \pm 0.0031$ \\
F10 & $11.54 \pm 0.65$ & $100.00 \pm 1.22$ & $60.64 \pm 0.90$ & $0.4175 \pm 0.0145$ & $0.0431 \pm 0.0047$ \\
\hline
\end{tabular}

Good flowability will produce uniform dosage form with constant filling granules in the compression room. The compactibility was showed by the tablet hardness after compaction, higher of compactibility of mass tablet then mass of tablet to be compressed with low pressure. Uniformity of dosage form was determined by the drug content of captopril tablet. Uniformity of dosage form as required in Indonesian Pharmacopecia IV, that the drug content not less than $85 \%$ and not more than $115 \%$ with the relative standard deviation not more than $6 \%$. The controlled hardness of tablet was expected that the hardness will not affect the drug release form dosage form. Tablet without matrix showed that the hardness was not in accordance with the prescribed. Low compactibility and low of the moisture content caused tablet capping when compressed with high pressure and cannot formed compact mass with hardness of 10-12kg. Hardness of tablet without matrix with the maximum pressure without occurrence of capping and lamination.

Drug release profile (Figure 2) showed that the drug release form of captopril sustained release tablet dosage form. In the initial release occurred initial burst release or the drug release uncontrolled, the matrices cannot control the drug release and the drug cannot loaded in the nanoporous of clays maximally.

Composite between drugs and clays were formed maximally at $60 \mathrm{~min}$ that showed the lower drug release rate. Nanocomposites were formed with the drug molecules adsorb on nanoporous of carrier materials (zeolite, hydrotalcite and montmorillonite), then the loaded drug in the nanoporous have hydrogen bonding interaction between the drug molecules and nanoclays making the drug release slowly. Clay materials are naturally occurring 


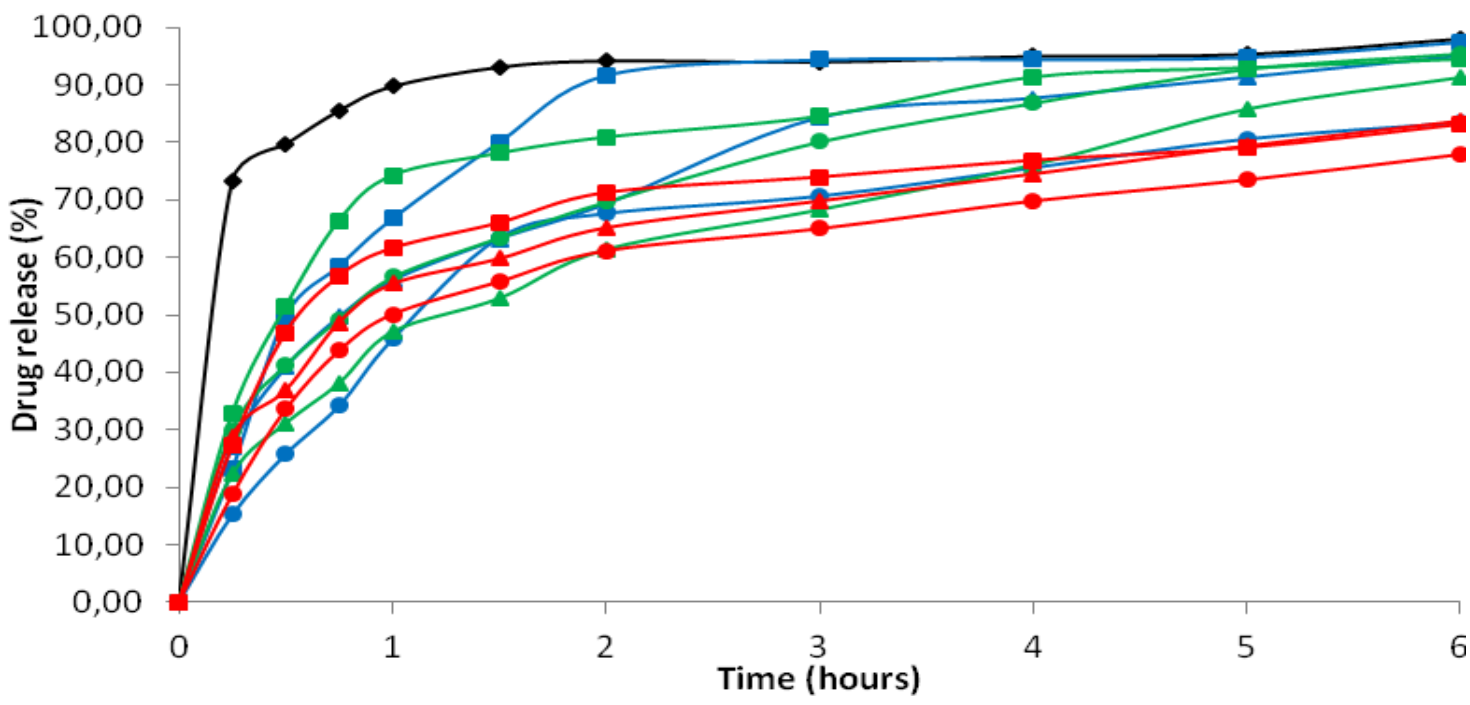

Figure 2. The drug release profile of captopril from dosage form ( - : without matrix, — : zeolite, — : hydrotalcite, _ : montmorillonite, - $:$ concentration $20 \%, \boldsymbol{\Lambda}$ : concentration $30 \%$, and $\bullet$ : concentration $40 \%$ )

cationic/anionic exchangers and so they may undergo in exchange with basic drug in solution. Release rate of the drug decreased with enhancement of the matrix concentrations.

F4 showed the lowest drug release rate, and F7 showed the fastest between the other formulas. The drug release showed the exponential/parabolic curve showed by the $\beta$ (shape parameter of Weibull's equation) $<1$, there are indicated that the initial release with higher slope in the initial. The drug release using 2 release models were initial burst release occurred at 0 until $60 \mathrm{~min}$ and maintenance release that occurred at $60-360 \mathrm{~min}$. Dissolution profile all formulas were compared with dissolution efficiency until 360 minutes $\left(\mathrm{DE}_{360}\right)$, initial burst release and maintenance release. The result showed significant different with value of $\mathrm{DE}_{360}(\mathrm{p}<0.05)$, initial burst release $(p<0.05)$ and maintenance release $(p<0.05)$. Release rate was determined by the profile pharmacokinetics approach of captopril with the rate of maintenance release more than $0.02 \mathrm{mg} / \mathrm{min}$ and approach the steady state concentration $(0.05 \mathrm{mg} / \mathrm{min})$ and the lowest initial burst release rate. Montmorillonit 40\% has been required the lowest of initial burst release rate and the expected of pharmacokinetics profile approach (steady state). The release mechanism based on diffusion exponential of Korsmeyer-Peppas equation. The exponential (n) equation was determined the release mechanism, fickian diffusion $(\mathrm{n}=0.45)$, anamolius transport $(0.45<\mathrm{n}<0.89)$, case II transport $(\mathrm{n}=0.89)$, and super case II transport $(\mathrm{n}>0.89)$ (Colombo et al. 2007). The mechanism release all formula showed that the mechanism release not followed the Korsmeyer-Peppas equation. Exponential value less than 0.45, the mechanism of release was unclassified. The mechanism release using 2 model of drug release because the nanocomposite of drug and clays, the composites were not occurred in the initial time. The best kinetic models to describe the release kinetics and fitting the equation based on goodness of fitting that the highest of coefficient determination $\left(\mathrm{R}^{2}\right)$, the lowest of AIC, and the lowest of RMSE that showed the similarity between observed data and predicted data (equation model) (Motulsky \& Chirtopoulos, 2003). The release kinetic was described by the Weibull's model. The drug release linear relation can be obtained for a log$\log$ plot of $-\ln (1-\mathrm{m})$ versus time (t) (Costa and Lobo, 2001). Ketoprofen, sodium diclofenac and chloramphenicol succinate loaded in the mesoporous of anionic clays (hydrotalcite) showed the initial burst release in $1 \mathrm{~h}$ and the 
Tabel IV. Kinetic models of drug release captopril tablet

\begin{tabular}{|c|c|c|c|c|c|c|c|c|c|c|}
\hline Models & Statistic & F2 & F3 & F4 & F5 & F6 & F7 & F8 & F9 & F10 \\
\hline \multirow{3}{*}{ zero-order } & $\mathrm{R}^{2}$ & 0.591 & 0.862 & 0.837 & 0.691 & 0.861 & 0.918 & 0.631 & 0.837 & 0.788 \\
\hline & RMSE & 15.86 & 8.14 & 8.71 & 10.66 & 8.12 & 5.99 & 10.59 & 6.90 & 8.16 \\
\hline & AIC & 82.91 & 68.95 & 70.32 & 74.36 & 69.51 & 62.82 & 74.22 & 65.64 & 69.02 \\
\hline \multirow{3}{*}{ first-order } & $\mathrm{R}^{2}$ & 0.473 & 0.736 & 0.649 & 0.560 & 0.714 & 0.814 & 0.484 & 0.718 & 0.613 \\
\hline & RMSE & 19.28 & 11.33 & 13.81 & 12.37 & 11.45 & 8.83 & 12.05 & 8.68 & 10.55 \\
\hline & AIC & 86.21 & 75.58 & 79.54 & 77.33 & 75.79 & 70.60 & 76.80 & 70.25 & 74.16 \\
\hline \multirow{3}{*}{ Higuchi } & $\mathrm{R}^{2}$ & 0.883 & 0.891 & 0.931 & 0.829 & 0.833 & 0.775 & 0.769 & 0.865 & 0.902 \\
\hline & RMSE & 8.75 & 7.40 & 5.65 & 7.68 & 8.88 & 9.93 & 10.12 & 8.77 & 10.77 \\
\hline & AIC & 69.65 & 65.69 & 61.66 & 71.17 & 70.70 & 72.94 & 77.67 & 70.46 & 64.57 \\
\hline \multirow{3}{*}{$\begin{array}{l}\text { Hixson- } \\
\text { Crowell }\end{array}$} & $\mathrm{R}^{2}$ & 0.514 & 0.784 & 0.719 & 0.605 & 0.768 & 0.853 & 0.533 & 0.760 & 0.676 \\
\hline & RMSE & 17.59 & 9.95 & 11.26 & 11.61 & 9.94 & 7.63 & 11.36 & 7.92 & 9.44 \\
\hline & AIC & 84.37 & 72.97 & 75.45 & 76.06 & 72.96 & 67.67 & 75.62 & 68.41 & 71.92 \\
\hline \multirow{4}{*}{ Weibull } & $\mathrm{R}^{2}$ & 0.938 & 0.994 & 0.966 & 0.975 & 0.987 & 0.976 & 0.896 & 0.985 & 0.953 \\
\hline & $\beta$ & 0.812 & 0.690 & 0.766 & 0.606 & 0.679 & 0.640 & 0.505 & 0.506 & 0.563 \\
\hline & RMSE & 3.45 & 1.67 & 3.76 & 2.78 & 2.52 & 2.80 & 5.12 & 2.03 & 3.20 \\
\hline & AIC & 51.81 & 37.30 & 53.52 & 47.50 & 45.51 & 47.63 & 59.68 & 41.23 & 50.27 \\
\hline \multirow{4}{*}{$\begin{array}{l}\text { Korsmeyer } \\
\text {-Peppas }\end{array}$} & $\mathrm{R}^{2}$ & 0.814 & 0.973 & 0.929 & 0.872 & 0.959 & 0.989 & 0.801 & 0.959 & 0.904 \\
\hline & $\mathrm{n}$ & 0.412 & 0.380 & 0.576 & 0.297 & 0.422 & 0.368 & 0.302 & 0.321 & 0.395 \\
\hline & RMSE & 2,66 & 3.33 & 5.17 & 8.16 & 3.91 & 2.03 & 6.83 & 0.310 & 4.41 \\
\hline & AIC & 74.63 & 51.10 & 59.89 & 63.37 & 54.28 & 41.16 & 65.48 & 49.64 & 56.71 \\
\hline
\end{tabular}

diffusional release mechanism (San Roman et al., 2013). The nanocomposites of ofloxacin with montmorillonite-chitosan reduced the initial burst release and the kinetic release followed the Higuchi equation and first-order kinetic (Hua et al., 2010).

\section{CONCLUSION}

Montmorillonite, zeolite and hydrotalcite were used as matrices captopril tablet could release the drug form dosage form with the sustained release with initial burst release and maintenance release. Montmorillonit $40 \%$ as matrix showed that the lowest initial burst release and expected maintenance release.

\section{ACKNOWLADGEMENT}

The research was supported by Hibah Madya Desentralisasi DIKTI batch I 2013 from The Ministry of Education Council Republic of Indonesia.

\section{REFERENCE}

Ainurofiq, A., Nurcahyo, I.F., Marchaban, and Wijaya, K., 2010. Nano Komposit NaMontmorillonit-Kitosan Sebagai Material
Pembawa Sediaan Lepas Lambat. Laporan Penelitian Hibah Pekerti. Universitas Sebelas Maret, Surakarta.

Anonymous, 1995, Farmakope Indonesia edisi IV, Departemen Kesehatan Republik Indonesia. Jakarta. pp. 999-1002.

Bruton, L., Parker K., Blumenthal, D., and Buxton, I., 2008, Goodman \& Gilman's: Manual of Pharmacology and Therapeutics. Mc Graw-Hill. New York. pp. 545-555.

Calvani, F., Trifiro, F., and Vaccari, A., 1991. Hidrotalcite-type anionic clays:preparation, properties and applications. Catalys Today. 11:173-301.

Collett, J., and Moreton, C., 2002. Modifiedrelease Peroral Dosage Form, in Aulton, M.E., Pharmaceutics: The Science Of Dosage Form Design. Ed. II. New York. pp. 289305.

Colombo, I., Lapasin, R., Grassi, G., and Grassi, M., 2007. Understanding Drug Release and Absorption Mecanisms : A Physical and Mathematical Approach. Taylor \& Francis Group. New York. pp.388411. 
Costa, P. and Lobo, J.M.S., 2001. Review : modeling and comparison of dissolution profile. Eur.J. Pharm. Sci. 13: 123-133.

Donald, G., Vidt, M.D., Emannuel, L., Bravo, M.D., Fetnat, M., and Fouad, M.D., 1982, Captopril. N. Engl. J. Med. 306 : 214-219.

Fudholi, A., 1983. Metodologi Formulasi Dalam Kompresi Direk. Medika, 7(9). $586-593$.

Gonzales, G., Saqarzazu, A., and Zoltan, T., 2013. Influence of microstructure in drug release behavior of silica nanocapsules. J. Drug Deliv., $1: 1-8$.

Hua, S.,Yang, H., and Wang, A., 2010. A pHsensitive nanocomposite microsphere based on chitosan and montmorillonite with in vitro reduction of the brust release effect. Drug Dev. and Ind. Pharm. 36(9):1106-1114.

Mendyk, A., Jachowicz, R., Fijorek, K., Dorozynski, P., Kulinowski, P., and Polak S., 2012. KinetDS : an open source software for dissolution test data analysis. Dissolution Technology 19(1): 6-11.

Motulsky, H. J., and Christopoulos, A., 2003. Fitting Model to Biological Data Using Linear And Nonlinear Regression : A Practical Guide to Curve Fitting. GraphPad. San Diego.pp.143-153.

San Roman, M.S., Holgado, M. J., Salinas, B., and Rives, V., 2013. Drug release from layered double hydroxides and from their polylactic acid (PLA) nanocomposites. Applied Clay Science. 71:1-7.

Suresh, R., Borkar, S.N., Sawant, V.A., Shende, V.S., and Dimble, S.K., 2010. Review article : nanoclays drug delivery system. Int. J. Pharm. Sci. and Nanotech. 3(2) : 901905.

Wijaya, K., Sugiaharti, E., Mudasir, Tahir., I., and Liawati, I., 2004. Sintesis komposit oksida besi montmorillonit dan uji stabilitas strukturnya terhadap asam sulfat. Indonesian J. Chem, 4(1):33-42.

Zheng, J.P., Luan, L., Wang, H.Y., Xi, L.F., and Yao, K.D., 2007, Study on ibuprofen/montmorillonite intercalation composites as drug release system. Applied Clay Science. $36: 297-301$.

Zhang, Y., Xu, C., He, Y., Wang, X., Xing, F., Qiu, H., Liu, Y., Ma, D., Lin, T., and Gao, J., 2011. Zeolit/polimer composite hollow microspheres containing antibiotics and in vitro drug release. $J$. Biomater. Sci. Polym. 22:4-6. 